\title{
Phytochemical Screening and Antibacterial Activity of Menthe Piperita, Artemisa Compestris L and Pelargonium Adoraitissimum Leaves Extracts from North Libya
}

\author{
Latifa Abdulmageed Yarboa ${ }^{1}$, Ahmad Belgasem Ibrahim², Wedad Melad Al-Adiwish ${ }^{2, *}$ \\ ${ }^{1}$ Department Botany, Faculty of Science, Zawia University, Zawia, Libya \\ ${ }^{2}$ Department Chemistry, Faculty of Science, Zawia University, Zawia, Libya \\ Email address: \\ wedad8073@yahoo.com(W.M. Al-Adiwish),Latifaurpoa79@gmail.com(L.A. Yarboa),ahmadbolgasem@gmail.com(A. B. Ibrahim ) \\ *Corresponding author
}

\section{To cite this article:}

Latifa Abdulmageed Yarboa, Ahmad Belgasem Ibrahim, Wedad Melad Al-Adiwish. Phytochemical Screening and Antibacterial Activity of Menthe Piperita, Artemisa Compestris L and Pelargonium Adoraitissimum Leaves Extracts from North Libya. Biomedical Statistics and Informatics. Vol. 3, No. 3, 2018, pp. 49-52. doi: 10.11648/j.bsi.20180303.12

Received: June 30, 2018; Accepted: July 30, 2018; Published: September 1, 2018

\begin{abstract}
Phytochemical screening of the menthe piperita, artemisa compestris L and pelargonium adoraitissimum leave extracts from north Libya revealed the presence of some bioactive components. Various chemical tests showed that the bioactive compounds are found in methanolic extracts of these plants such as flavonoid, alkaloids, resins, terpineol, volatile oils and tannin groups. Saponin is present in Pelargonium adoraitissimum while it is absent in Menthe piperit and Artemisa compestris. The effects of methanolic extracts on some pathogenic: two strains of gram negative bacteria [Escherichia coli and Klebsiella pneumonia] and two strains of gram positive bacteria [Staphylococcus aureus and strrptococcus spp.] indiated that the menthe piperita has greater inhibition zone against two tested Gram negative bacteria and strains of gram positive bacteria.
\end{abstract}

Keywords: Phytochemical Screening, Antibacterial Activity, Medicinal Plants

\section{Introduction}

Most plants are important as a "food source". For example, proteins and fats have high nutritional value [1] because they contain energy sources Of carbohydrates They also have medical and therapeutic benefits as they are used in treating many diseases[2, 3], including asthma, worms, and also in urinary tract infections, Bronchial infections, aldecy cough, and skin allergies $[4,5]$. There are many medicinal plants such as Lawsonia inermis, Cuminum cyminum, Coriandrum, Zingiber officinale, Castor oil, and Black Cumin. These plants contain chemical compounds which have a clear biological effect against various bacteria and fungi [3].

The menthe piperita L. is one of the most important medicinal and aromatic plants. It has many immense therapeutic uses and has been used in medicine since thousands of years. For example, the babylonians used it in treating indigestion and the Chinese used it treating colic whereas the Romans used it in treating detoxification and poisoning [6, 7]. It is used as a disinfectant and in mouth washes, gums and toothpastes. As it relaxes the muscles, it may also help in relieving painful cramps, in treating colds and flu [8]. Some experiments have shown that menthe has the ability to treat asthma, inflammation of the sinuses and to reduce abdominal pain, and colic [9].

Artemisia campestris L. is an Asteraceae species and a perennial herb, commonly known as a field worm wood. It is widespread in Asia, North America, and Europe and predominates the arid regions of North Africa. Artemisia campestris has many medicinal actions, including: antivenom $[10,11]$, anthelmintic [12], antimicrobial, antifungal, anticancer [13], antidiabetic [14, 15, 16], antihypertensive. It has been utilized in treating many conditions, including: digestive, respiratory, cutaneous and genital diseases [17-22]. Some scientific studies on Artemisia campestris L showed the presence of constituents which belong mainly to the groups of essential oils, fatty acids flavonoids, coumarins, isocoumarins and phenolic acids.

The Pelargonium adoraitissimum belongs to Geraniaceae 
family and represents important sources of food, medicines and cosmetics and of distilled volatile oils [23-27]. These genera have been found to possess significant pharmacological and biological activities, including antioxidant, anti-neuroinflammatory, antiinfluenza, anticancer, antimicrobial and antifungal activity [23, 24, $27-$ 30]. It is used in folk medicine in Libya and in the world. as a food and tea, additive drinks and in relieving some gastrointestinal, topical, dental and cardiovascular disorders $[24,25,27,31]$. The phytochemical profile of Pelargonium has shown abundance of essential oils, phenolics and flavonoid [24, 27-29, 32-35]. The interest in secreted materials of menthe piperita, Artemisa compestris L and Pelargonium adoraitissimum for pharmaceutical products and spices led the researchers to study them. This study therefore aims to carry out a preliminary screening for the important phytochemical bioactive compounds and to investigate in vitro the antibacterial activity of methanolic leave extracts.

\section{Materials and Methods}

\subsection{Collection of Plant Materials}

Fresh leaves of menthe piperita, artemisa compestris L and pelargonium adoraitissimum were collected locally from Zawia, Libya and were identified by the Department of Botany, University of Zawia. The menthe piperita, artemisa compestris $\mathrm{L}$ and pelargonium adoraitissimum leaves were exposed to shed drying and grind by an electric grinder to turn it into a fine powder. Then, the powder was saved in a sterilized and tightly packed glass container which was stored in a cool place not exposed to light until use.

\subsection{Preparation of Extracts}

5 grams of each selected dried plant powder were weighed and added to a $50 \mathrm{ml}$ of methanol in a conical flask of a 200 $\mathrm{ml}$ capacity. The flask was covered and left aside for 24 hours. The plant mixture was mixed by a magnetic mixer and was left to be filtered. Then, the plant extract was kept in the refrigerator until use.

\subsection{Preliminary Phytochemical Screening}

Screening of the above three selected medicinal plants for various phytochemical constituents were carried out through using standard methods [36-38]. Qualitative phytochemical screening of plant extracts were carried out using the following methods to test only for the presence of secondary metabolites.

Test for Tannins: $0.008 \mathrm{M}$ Potassium ferricyanide was added to $1 \mathrm{ml}$ of the extract in a test tube. $1 \mathrm{ml}$ of $0.02 \mathrm{M}$ Ferric chloride containing $0.1 \mathrm{~N}$ hydrochloric acid was also added. A blue-black coloration was observed.

Test for Saponins: $5 \mathrm{ml}$ of distilled water was added to crude extract. The mixture was shaken in vigorously with some drops of olive oil in a test tube. Stable foam was observed which was considered as an indication of the presence of saponins.

Test for Flavonoids: Crude extract was added to $5 \mathrm{ml}$ of diluted ammonia solution and concentrated $\mathrm{H}_{2} \mathrm{SO}_{4}$. Yellow coloration which disappeared on standing indicates the presence of flavonoids.

Test for Terpenoids (Salkowski test): $2 \mathrm{ml}$ of chloroform and $3 \mathrm{ml}$ of concentrated $\mathrm{H}_{2} \mathrm{SO}_{4}$ was added to $5 \mathrm{ml}$ of extract to form a layer of reddish brown colouration.

Test for resins: The plant extract was boiled and added to distilled water in case turbidity in solution was visible; it is considered an indication of the existence of resins.

Test for volatile oils: During the vaporization of plant extract by a vaporizer, the emergence of an oily layer that was separated from the alcohol layer directly after several minutes of the vaporization process represents an indication of volatile oils content.

Test for Alkaloids: Curde extract was dissolved with $2 \mathrm{ml}$ of $1 \% \mathrm{HCl}$ and heated gently. Mayers reagents were added to the mixture. Turbidity of the resulting precipitate was taken as a confirmation for the presence of alkaloids.

\subsection{Antibacterial Assay}

The antibacterial activity of menthe piperita, artemisa compestris $\mathrm{L}$ and pelargonium adoraitissimum leaves methanolic extract was evaluated using the agar diffusion technique [39]. The tested organisms were Gram-positive bacteria [Staphylococcus aureus and Streptococcus spp] and Gram-negative bacteria [Escherichia coli and Klebsiella pneumonia]. The bacteria were maintained in nutrient agar media, respectively. After $24 \mathrm{~h}$ incubation at $37{ }^{0} \mathrm{C}$, the diameter $(\mathrm{mm})$ of the inhibition zones was measured.

\section{Result \& Discussion}

\subsection{Phytochemical Screening}

The extract of the leaves of the tested plants (menthe piperita, artemisa compestris $\mathrm{L}$ and pelargonium adoraitissimum) showed a positive result for the presence of medicinally active constituents. The Preliminary phytochemical screening of the tested plants is summarized in Table 1. In the methanolic extract; tanins, resins, flavonoids, alkaloids, terpenoids, alkaloids and volatile oils were most commonly found in the tested plants. Saponin is present in pelargonium adoraitissimum while it is absent in menthe piperit and artemisa compestris. These finding correlated well with several earlier publications [40]. Plants were rich in a wide variety of secondary metabolites such as terpenoids, alkaloids, tannins, flavonoids appears biological and pharmacological activities. These may have potential to be used as chemotherapeutic agents or serve as starting material in the developing of new antibiotics [41]. 
Table 1. Preliminary phytochemical screening of menthe piperita, artemisa compestris L and pelargonium adoraitissimum leaves extract.

\begin{tabular}{|c|c|c|c|c|c|c|c|}
\hline \multirow{2}{*}{ leaves methanolic extract } & \multicolumn{7}{|c|}{ phytochemical compounds } \\
\hline & Tannins & Flavonoids & Saponins & Alkaloids & Resins & Terpenoids & Volatile oils \\
\hline Menthe piperita & +++ & + & - & +++ & +++ & +++ & +++ \\
\hline Artemisa compestris & +++ & +++ & - & ++ & +++ & +++ & +++ \\
\hline Pelargonium adoraitissimum & +++ & +++ & + & ++ & +++ & +++ & +++ \\
\hline
\end{tabular}

$(+++)$ high $(++)$ medium $(+)$ poor $(-)$ no found

\subsection{Antibacterial Activity}

Methanolic extracts of tested plants show a varying degree for antibacterial activity (Table 2). The leaf menthe extract, showed a maximum zone of inhibition $(35 \mathrm{~mm})$ against Staphylococcus aureus which is a gram-positive bacteria. This kind of bacteria can cause various skin and soft tissue infections [42] particularly when skin or mucosal barriers have been breached. On the other hand, it shows a moderate activity against Escherichia coli by menthe extract. The methanolic extracts of artemisia campestins and pelargonium adoraitissimum showed an inhibition zone from 10-30mm against organism tested. The bioactive compounds plays an important role in our health such as flavonoids, essential oils, polyphenol and Terpens [43]. Widely of pathogens and resistant's bacteria were urgent needed of new antimicrobial agents, natural products which have inhibited of many organism causing harm disease of human [44].

Our results are in agreement with the results of Modupe [45], which found that, the antibacterial activity is attributed to high concentration of carvon; which is essential oil. the lipophilic nature of essential oils enables the oil to cross the cell membrane and reach the cytoplasm to play an active biological role [46].

Table 2. Inhibition zone (mean diameter of inhibition in $\mathrm{mm}$ ), of menthe piperita, artemisa compestris L and pelargonium adoraitissimum leaves extract.

\begin{tabular}{|c|c|c|c|c|}
\hline \multirow{3}{*}{ Plant extracts } & \multicolumn{2}{|l|}{ Gram-positive bacteria } & \multicolumn{2}{|l|}{ Gram-negative bacteria } \\
\hline & Streptcoccus spp & Staphylococcus aureus & Escherichia coli & Klebsiella pneumonia \\
\hline & Inhibition zone (mm) & & Inhibition zone (mm) & \\
\hline Pelargonium adoraitissimum & 10 & 14 & 12 & 12 \\
\hline Menthe piperita & 25 & 35 & 14 & 33 \\
\hline Artemisa compestris & 20 & 30 & 20 & 20 \\
\hline
\end{tabular}

\section{Conclusion}

Phytochemical analysis and an antimicrobial study of medicinal plants is a very significant way to establish that the selected plant species may be used as potent drugs. The high cost and side effects of synthesized drugs are forcing the scientists to research alternative sources for the treatment of diseases. Saponins, terpenes, glycosides, Essential oils and polyphenols are a very promising drug discovery.

In this study, it is found that the presence of tanins, resins, flavonoids alkaloids, terpenoids, alkaloids and volatile oils in the tested plants can be used as an important source of phytochemical and antimicrobial activity. On the basis of this antibacterial study, it is clear that the selected plant shows a significant antibacterial activity against selected bacteria strains. Therefore, this study indicates that these plants may be used as potent antibacterial drugs of natural origin. A further work may emphasize the isolation and characterization of effective compounds.

\section{References}

[1] Moor R, Clark, W. D and Vodopich, D. S., Botany", 2nd.ed., McGraw Hill Companies, Inc., USA. (1998).

[2] Al-Rawi, A. and Chakaraverty, H. L. Medicinal plants of Iraq", 2nd.ed. Ministry of Agriculture and Irrigation, Baghdad Iraq. (1988).
[3] Anesini, G. and Perez, C. "Screening of Plants Used Agrentine Folk Medicine for Antimicrobial Activity", J. Ethnopharmacology, 39, 119-128. (1993).

[4] Qureshi, S; Shah, A. H., Tariq, M. and Aqeel, A. M., "Studies on Herbal Aphrodislacs Used in Arab System of Medicine"., American J. of Chinese Medicine, 5 (no.1-2), 57-63..(1989).

[5] Perrot, E. and Paris, R. "Les Plants Medicinales" Vol.2, Presses Universitarries de France-Vedome.. (1971).

[6] Briggs, C. peppermint: Medicinal Herb and Flavouring Agent. CPJ/ RPC 8992, 1993.

[7] Evans, W. C. Trease and Evans Pharmocogensy. 14thed. W. B. Sannders Company Ltd., London, 1999.

[8] Sparks, M. J., P. O, Sullivan, A. A. Herrington, S. K. Morcos. Dose peppermint oil relieve spasm during barium enema? Br J Radiol 68 (812):841-843, 1995.

[9] Longe, J. L. The Gale Encyclopedia of Alternative Medicine. Farmington Hills, MI: Thomson/Gale, 2005.

[10] Bahekar, S., Kale, R., Nagpure, S., 2012. A review on medicinal plants used in scorpion bite treatment in India. Int. J. Pharm. Med. Sci. 1, 1-6.

[11] Kapoor, S., Saraf, S., 2011. Topical herbal therapies an alternative and complementary choice to combat acne. Res. J. Med. Plant 5, 650-669.

[12] De Natale, A., Pollio, A., 2012. A forgotten collection: the libyan ethnobotanical exhibits (1912-14) by A. trotter at the museum O. comes at the university federico II in naples, Italy. J. Ethnobiol. Ethnomed. 8, 1-19. 
[13] Naghibi, F., Khalaj, A., Mosaddegh, M., Malekmohamadi, M., Hamzeloo-Moghadam, M., 2014. Cytotoxic activity evaluation of some medicinal plants, selected from Iranian traditional medicine Pharmacopoeia to treat cancer and related disorders. J. Ethnopharmacol. 155, 230-239.

[14] Bnouham, M., Mekhfi, H., Legssyer, A., Ziyyat, A., 2002. Ethnopharmacology forum medicinal plants used in the treatment of diabetes in Morocco. Int. J. Diabetes Metab. 10, 33-50.

[15] El Hassani, M., Douiri, E. M., Bammi, J., Zidane, L., Badoc, A., Douira, A., 2013. Plantes médicinales de la moyenne moulouya (Nord-Est du Maroc). Ethnopharmacologia 50, 39-53.

[16] Fakchich, J., Elachouri, M., 2014. Ethnobotanical survey of medicinal plants used by people in Oriental Morocco to manage various ailments. J. Ethnopharmacol. 154, 76-87.

[17] Benchelah, A.-C., Bouziane, H., Maka, M., 2004. Fleurs du Sahara, arbres et arbustes, voyage au coeur de leurs usages avec les Touaregs du Tassili. Phytothérapie 2, 191-197.

[18] Boudjelal, A., Henchiri, C., Sari, M., Sarri, D., Hendel, N., Benkhaled, A., et al., 2013. Herbalists and wild medicinal plants in M'Sila (North Algeria): An ethnopharmacology survey. J. Ethnopharmacol. 148, 395-402.

[19] Boulanouar, B., Abdelaziz, G., Aazza, S., Gago, C., Miguel, M. G., 2013. Antioxidant activities of eight Algerian plant extracts and two essential oils. Ind. Crops Prod. 46, 85-96.

[20] Djidel, S., Khennouf, S., Baghiani, A., Harzallah, D., Arrar, L., 2009. Medicinal plants used traditionally in the Algerian folk medicine for gastrointestinal disorders and hypertension: total polyphenols, flavonoids and antioxidant activity. Acta Hortic 854, 59-65.

[21] Fakchich, J., Elachouri, M., 2014. Ethnobotanical survey of medicinal plants used by people in Oriental Morocco to manage various ailments. J. Ethnopharmacol. 154, 76-87.

[22] Hammiche, V., Maiza, K., 2006. Traditional medicine in central sahara: pharmacopoeia of tassili N'ajjer. J. Ethnopharmacol. 105, 358-367.

[23] Zargari A (1989). Medicinal Plants. 4thed (in Persian). Tehran University Publications. Tehran, IRAN.

[24] Zargari A (1990). Medicinal Plants. 5thed (in Persian).

[25] Plants of Iran (in Persian). Tehran University of Medical Sciences Publications, Tehran, IRAN.

[26] Mozaffarian V (1996). A Dictionary of Iranian Plant Names. Farhange Moasser, Tehran, IRAN.

[27] Andrade MA, Cardoso MG, Batista LR, Freire JM, Nelson DL. Antimicrobial activity and chemical composition of essential oil of Pelargonium odoratissimum. Braz J Pharmacognosy 2011; 21: 47-52.

[28] Elmann A, Mordechay S, Rindner M, Ravid U. Antineuroinflammatory effects of geranium oil in microglial cells, J Func Food 2010; 2: 17-22.

[29] Fayed SA. Antioxidant and anticancer activities of Citrus reticulate (Petitgrain Mandarin) and Pelargonium graveolens (Geranium) essential oils. Res J Agric Biolm Sci 2009; 5: 740747.

[30] Stojkovic D, Sokovich M, Glamoclija J, Dzamic A, Ciric A, Ristic $M$, et al. Chemical composition and antimicrobial activity of Vitex agnus-castus L. fruits and leaves essential oil. Food Chem 2011; 128: 1017-1022.

[31] Meena AK, Singh U, Yadav AK. Singh B, Rao MM. Pharmacological andphytochemical evidences for the extracts from plants of the genus Vitex- A review. Int J Pharm Clinic Res 2010; 2: 1-9.

[32] Lis-Balchin M. Essential oil profiles and their possible use in hybridization of some common scented Geraniums. J Essent Oil Res 1991; 3: 99-195.

[33] Jalali-Heravi M, Zekavat B, Sereshti H. Characterization of essential oil components of Iranian geranium oil using gas chromatography-mass spectrometry combined with chemometric techniques. J Chromatogr 2006; 1114: 154-163.

[34] Babu KGD, Kaul VK. Variation in essential oil composition of rose-scented geranium (Pelargonium sp.) distilled by different distillation techniques. Flavour Frag J 2005; 20: 222-231.

[35] Arokiyaraj S, Perinbam K, Agastian P, Kumar MR. Phytochemical analysis and antibacterial activity of Vitex agnus-castus. Int J Green Pharm 2009; 3: 162-164.

[36] Sofowara A. Medicinal plants and traditional medicine in Africa. Spectrum Books Ltd., Ibadan: Nigeria. 1993, 289-300.

[37] Harborne JB. Phytochemical Methods. Chapman and hall Ltd., London: U.K., 1973, 49-188.

[38] Ogbuewu IP. Physiological responses of rabbits fed graded levels of neem (Azadirachta indica) leaf meal. Federal University of Technology: Owerri, 2008.

[39] Clinical and Laboratory Standards Institute, Performance Standards for Antimicrobial Disk Susceptibility Test. Approved Standard, ninth ed., CLSI, Wayne, PA, USA, 2006.

[40] Pramila, D. M., Xavier, R., Marimuthu, K., Kathiresan, S., Khoo, M. L., Senthilkumar, M., Sathya, K. and Sreeramanan, S, Phytochemical analysis and antimicrobial potential of methanolic leaf extract of peppermint (Mentha piperita: Lamiaceae), Journal of Medicinal Plants Research Vol. 6(2), pp. 331-335, 16 January, 2012.

[41] Waseem Ahmad, Shilpa Singh and Sanjay Kumar, Phytochemical Screening and antimicrobial study of Euphorbia hirta extracts, Journal of Medicinal Plants Studies 2017; 5(2): 183-186.

[42] Qing Rao, Weilong Shang, Xiaomei Hu and Xiancai Rao, Staphylococcus aureus ST121: a globally disseminated hypervirulent clone, Journal of Medical Microbiology (2015), $64,1462-1473$.

[43] Yadav RNS, Agarwala M. Journal of Phytology. 2011; 3:10

[44] Akinnmade JF, Oyeleye OA, Journal Biotechnology. 2010; 9:5028.

[45] Modupe Elizabeth Ojewumi, Samuel Oluwafunsho Adedokun, Oladele Julius Omodara, Esther Adenike Oyeniyi, Olugbenga Samson Taiwo, EmmanuelOmotayo Ojewumi, Phytochemical and Antimicrobial Activities of the Leaf Oil Extract of Mentha Spicata and its Efficacy in Repelling Mosquito, Int. J. Pharm. Res. Allied Sci., 2017, 6(4):17-27.

[46] Gautam, N., A. K. Mantha, and S. Mittal. 2014. Essential oils and their constituents as anticancer agents: A mechanistic view. BioMed Research International 2014 (2014): Article $154106,23 \mathrm{p}$. 